\title{
POJEM OSOBNOSTI V DIELE RUSKÉHO FILOZOFA NIKOLAJA ALEXANDROVIČA BERĎAJEVA (VYVRCHOLENIE PERSONALISTICKEJ LÍNIE SLOVANSKÉHO MYSLENIA) ${ }^{1}$
}

\author{
The Concept of Personality in the Work of Russian Philosopher \\ Nikolai Alexandrovich Berdyaev \\ (Climax of the Personalistic Line of Slavic Thought)
}

\author{
Milan Petkanič
}

DOI: 10.17846/CL.2018.11.1.130-137

\begin{abstract}
PETKANIČ, Milan. The Concept of Personality in the Work of Russian Philosopher Nikolai Alexandrovich Berdyaev (Climax of the Personalistic Line of Slavic Thought). The paper provides an analysis of the main features of personality in the work of N. A. Berdyaev, who belongs to the most prominent authors of the personalistic line of Slavic philosophy. It is primarily concerned with Berdyaev's principal book Slavery and Freedom (1939), which elaborates this theme most thoroughly. Berdyaev's concept of personality is here interpreted in correlation with other central concepts of his work, above all with freedom and spirit both are exposed as the inherent attributes of personality. While Berdyaev's metaphysics is based on duality of spirit and nature, or freedom and necessity, the paper points to his concept of person(ality) as based on triple structure: spirit, soul and body. The paper also examines Berdyaev's fundamental conceptual distinctions between personality and individual and outlines the differences in standpoints of personalism and individualism, while the latter is shown as opposed to the former.
\end{abstract}

Keywords: Russian philosophy, personality, person, individual, spirit, freedom, objectification, universal, microcosm, personalism $v$ s. individualism

Abstrakt: PETKANIČ, Milan. Pojem osobnosti v diele ruského filozofa Nikolaja Alexandroviča Berdajeva (Vyvrcholenie personalistickej línie slovanského myslenia). Ústrednou ambíciou môjho príspevku je analyzovat hlavné črty osobnosti v diele N. A. Berdajeva, ktorý patrí medzi najprominentnejších autorov personalistickej línie slovanskej filozofie. V príspevku sa preto primárne opieram o Berdajevovu principiálnu knihu $O$ otroctve a slobode človeka (1939), v ktorej autor najdôkladnejšie rozvinul tému osobnosti. Berdajevov pojem osobnosti tu interpretujem v korelácii s dalšími centrálnymi pojmami jeho tvorby, predovšetkým s pojmami slobody a ducha, pričom ich predstavujem ako dva základné piliere jeho konceptu osobnosti. V práci poukazujem na to, že zatial čo Berdajevova metafyzika je založená na dualizme ducha a prírody, resp. slobody a nutnosti, jeho koncept osobnosti sa vyznačuje triadickou štruktúrou: duch, duša a telo. V štúdii sa taktiež snažím objasnit Berdajevov kon-

Predložený text je výstupom z riešenia projektu VEGA č. 1/0124/16 Ruská a slovenská filozofia osoby $v$ lingvistických a filozofických súvislostiach. 
ceptuálny rozdiel medzi osobnostou a indivíduom, ako aj zadefinovat základný rozdiel až kontrapozíciu medzi personalizmom a individualizmom.

Klúčové slová: ruská filozofia, osobnost’, osoba, indivíduum, duch, sloboda, objektivácia, univerzálne, mikrokozmos, personalizmus vs. individualizmus

Vo svojom článku by som chcel objasnit jeden z centrálnych konceptov diela významného ruského myslitela 20. storočia Nikolaja Alexandroviča Berdajeva (1874-1948), a to koncept osobnosti, ktorý autor najdôkladnejšie rozvinul vo svojej principiálnej knihe O otroctve a slobode človeka s podtitulom Pokus o personalistickú filozofiu publikovanej v roku 1939. Berúc na zretel' limity stanovené pre jednotlivé štúdie $\mathrm{v}$ tomto časopise sa však obmedzím len na tie najdôležitejšie a z môjho pohladu aj najzaujímavejšie znaky osobnosti v Berdajevovej filozofii. Navzdory faktu, že Berdajev explicitne formuluje vlastnú originálnu koncepciu osobnosti až k záveru svojho autorsky mimoriadne plodného života, nie je personalizmus filozofickým stanoviskom, ku ktorému dospieva až v tejto záverečnej fáze svojho života a ani nie je v jeho filozofickom korpuse len nejakou okrajovou záležitostou, ale stojí, i podla jeho vlastných slov, v samotnom základe jeho celostného filozofického názoru (Berd’ajev 1997, 9).

Svoje úvahy o osobnosti v spomínanom diele začína Berdajev tým, že nazýva človeka tou najväčšou hádankou sveta. Súčasne však podotýka, že pokým nahliadame na človeka ako na sociálnu alebo prírodnú bytost', nebude pre nás žiadnou hádankou, žiadnym tajomstvom. Totiž iba ako osobnost', t. j. ako jedinečná bytost’ s jedinečným údelom je pre nás človek skutočnou hádankou a tajomstvom. Optika špeciálnych vied je jednak vždy čiastková, preto nám biologické, sociologické či psychologické skúmania človeka ponúkajú len fragmentárne poznanie a jednak pristupuje k človeku zakaždým akoby zvonku, nahliada naň ako na objekt, vec medzi vecami, exemplár svojho druhu, preto im je tajomstvo osobnosti skryté. Osobnost' ale v kontraste k špeciálno-vednému bádaniu odkazuje, podla Berdajeva, na jedinečnost', celistvost’ a subjektivitu. S otázkou poznatelnosti človeka bezprostredne súvisí Berdajevovo zásadné rozlišovanie medzi človekom ako osobnostou a človekom ako indivíduom. Kým indivíduum je predmetom špeciálnych vied, centrálnou témou personalistickej filozofie je osobnost. ${ }^{2}$ Ak by sme si na tomto mieste vypomohli konceptuálnou dištinkciou medzi problémom a tajomstvom z pera francúzskeho katolíckeho existencialistu Gabriela Marcela (pozri: Marcel 1971, 9nn), tak by sme mohli povedat, že pojmom indivíduum Berdajev odkazuje na to, čo je objektívne poznatelné na človeku, to znamená to, čo je na ňom predmetné, a to sa stáva problémom špeciálnych vied. Oproti indivíduu sa osobnost̉ nemôže stat predmetom, objektom poznania, a teda problémom, ktorý tu vystupuje pred nami a ktorý má v princípe objektívne riešenie. Osobnosț tak pre nás navždy zostane tajomstvom. Tajomstvo nie je však podla Marcela niečo, čo tu vystupuje $\mathrm{v}$ dostatočnom odstupe predo mnou, ale je tým, čo ma zasahuje priamo dovnútra; poznanie tajomstva je preto možné len istým druhom osobnej účasti. A podobne i Berdajev je presvedčený, že isté poznanie osobnosti je predsa len možné, a to ponorením sa do vlastnej subjektivity, a teda prostredníctvom osobnej a duchovnej skúsenosti: „Osobnost̉ možno poznat' len ako subjekt, v nekonečnej subjektivite, v nej sa skrýva tajomstvo existencie“ (Berd’ajev 1997, 21). V tomto kontexte sa azda najviac odhaluje hlboko existenciálny charakter Berdajevovho personalizmu. $^{3}$

Pojmovú diferenciu medzi indivíduom a osobnostou ešte bližšie rozvedieme v dalších častiach textu.

3 Stojí za zmienku, že Berdajev sa otvorene hlási k existenciálnej filozofii, resp. k existencializmu, hoci s mnohými autormi zvyčajne radenými do tohto smeru sa zásadne rozchádza (najexplicitnejšie s M. Heideggerom a J. P. Sartrom, pričom prvého menovaného dokonca ani za existenciálneho myslitela nepovažuje - pozri napr.: Berdajev 2003, 10-11). 
S určitou mierou zovšeobecnenia môžeme konštatovat', že v Berd’ajevovej personalistickej koncepcii človeka sú základnými stavebnými prvkami osobnosti duch a sloboda. ${ }^{4}$ Pokial' ide o ducha, treba vziat do úvahy, na čo Berd’ajev na mnohých miestach upozorňuje, že ducha v žiadnom prípade nemožno chápat objektívne - to bol totiž zásadný omyl idealizmu. Podla neho totiž v skutočnosti nejestvuje niečo také ako objektívny alebo kolektívny duch, nanajvýš ak v symbolickej rovine. Ako píše vo svojej knihe Duch a realita (1937): „V striktnom zmysle slova možno hovorit” len o osobnom a subjektívnom duchu“ (Berdajev 2006, 38). Duch totiž prebýva v subjektivite, v osobnosti. Práve duch a sloboda sú od osobnosti neodmyslitelné, a preto ich musíme predpokladat v každom názore na človeka ako osobnost’ - nie je totiž možné formulovat materialistickú alebo deterministickú koncepciu osobnosti. „Človek nie je osobnostou kvôli svojej prirodzenosti, ale kvôli svojmu duchu. Prirodzenosti zodpovedá len indivíduum“ (Berdajev 1997, 20). A človek je osobnostou nielen vdaka duchu, ale i vd’aka slobode: „Existencia osobnosti predpokladá slobodu. Tajomstvo slobody je tajomstvom osobnosti“ (Berd’ajev 1997, 24). Ako píše Martin Jabůrek $(2013,93)$, komentujúc Berd’ajevovu filozofiu osobnosti: „Osoba je skutočná natol'ko, nakol'ko je skutočná sloboda, skutočným vyjadrením a reálnym garantom slobody je osoba“. Duch a sloboda sú však v Berd’ajevovej filozofii natolko navzájom prestúpené pojmy, že ich dokonca miestami stotožňuje: „Duch je sloboda, a sloboda je duch“ (Berdajev 2005, 44). Skúsenost slobody, ktorú Berd’ajev vždy chápe ako slobodu ducha (na rozdiel od školského pojmu slobody vôle), je pre neho tou „prvotnou skúsenostou“ (Berd’ajev 2005, 38), nespochybnitelným faktom a základným východiskom, z ktorého potom odvodzuje i celú svoju filozofiu, vrátane filozofie osobnosti. Osobnost’ ako slobodná bytost’ odporuje všetkej determinácii, vonkajšej i vnútornej, s výnimkou vnútornej determinácie sama sebou. „Osobnost’ je aktivitou, odporom, vítazstvom, triumfom slobody nad otroctvom sveta“ (Berd’ajev 1997, 22).

Osobnost’ a sloboda pri realizácii predpokladajú odpor, a preto so sebou nesú bolest’a utrpenie. Sloboda podla Berdajeva neznamená nejakú lahkost', odlahčenie, ako je tomu v prípade liberálneho a libertínskeho chápania slobody ako volnosti a nezáväznosti, pravá sloboda je naopak tažká, heroická a tragická. Osobnost musí totiž na ceste k svojej realizácii prejst tragickými protikladmi. Azda najlepšie to opisuje Berd’ajev $(1997,25)$ v nasledujúcej pasáži: „Sebauskutočnenie osobnosti predpokladá odpor, žiada si boj proti zotročujúcej moci sveta, nesúhlas s konformným vztahom k svetu. Zrieknutie sa osobnosti, dobrovolné rozpustenie seba samého v okolitom svete môžu zmiernit bolest’ a človek sa s tým lahko zmieruje. Súhlas s otroctvom tíši bolest', nesúhlas ju jatrí. Bolest' v ludskom svete je zrodená osobnostou, jej bojom za vlastný obraz... Sloboda pôsobí utrpenie. Môžeme zmenšit utrpenie, ak sa vzdáme slobody“. Jedna z hlbokých múdrostí, ktorým sa Berdajev naučil u F. M. Dostojevského, je myšlienka, že sloboda a štastie sa k sebe chovajú nepriatel'sky. Berd’ajev $(2000,122)$, interpretujúc Dostojevského „Legendu o Velkom inkvizítorovi“, poznamenáva: „[s]loboda l’udského ducha nie je zlúčitelná s ludským štastím“. Z toho dôvodu stojí každá ludská bytost vo svojom živote pred taživou existenciálnou dilemou: „sloboda s utrpením alebo štastie bez slobody." (Berd’ajev 2000,121). A tejto myšlienke zostáva Berd’ajev verný po celý svoj život. K jeho záveru vo svojej filozofickej autobiografii, kde v sebareflexii v kontexte svojho života zhodnocuje celoživotnú tvorbu, tvrdí: „Personalizmus je v protiklade k eudaimonizmu.“ (Berdajev 2005, 48). Po celú tvorbu sa Berd’ajev obracia proti každej forme etického eudaimonizmu ako nekompatibilného stanoviska s filozofiou slobody a osobnosti, pretože štastie nemá vskutku žiadnu duchovnú kvalitu, hodnotu, a teda sa nemôže stat ústredným životným cielom človeka - tento názor je vel’mi blízky stanovisku dánskeho existenciálneho náboženského myslitela Sørena Kierkegaarda $(1993,134)$, ktorý tvrdí, že „štastie samotné k duchovnému určeniu

4 Pojmy ducha a slobody možno identifikovat ako dva základné piliere nielen Berdajevovej koncepcie osobnosti, ale i celku jeho myslenia, ako to navrhuje vo svojej štúdii Ján Letz $(2004,34)$. 
nepatrí. A kvalitatívnu verziu etického eudaimonizmu v podobe Millovho umierneného utilitarizmu pokladá Berd’ajev za vnútorne rozpornú (Berdajev 2005, 48).

Vrátme sa ešte $k$ Berdajevovmu zásadnému rozlišovaniu medzi pojmami osobnosti a indivídua načrtnutému doposial'len v kontexte problému poznatel’nosti človeka. Zatial' čo indivíduum je kategóriou biologickou či sociálnou, osobnost’ je podla jeho učenia kategóriou duchovnou. A kým osobnost' nie je podla Berdajeva častou žiadneho celku, a preto mu ani nemôže byt’ podriadená, indivíduum je vždy súčastou nejakého celku (kozmického, rodového, sociálneho), nech už by sa voči nemu akokolvek snažilo vymedzit a od ostatných častí egocentricky izolovat'. To, že osobnost' nie je častou žiadneho univerza, rodu, spoločnosti, zároveň značí, že im ani nie nijak podriadená, a že nimi nie je determinovaná. Indivíduum naopak, súc častou nejakého celku, je vždy závislé od tohto celku. Každý človek je na jednej strane indivíduom, teda je súčastou materiálneho sveta, sveta kozmického, rodového a sociálneho. Ale každý človek je taktiež aj osobnostou, a ako osobnost' vydáva svedectvo o existencii iného sveta. Človek ako osobnost̉ je totiž priesečníkom dvoch svetov: sveta ducha a sveta prírody. Personalizmus musí podla Berdajeva vychádzat’ $z$ duality sveta, metafyzický monizmus vníma Berd’ajev ako zásadne nekompatibilný s filozofiou osobnosti (pozri napr.: Berdajev 1997, 29). Osobnost je tým miestom, kde dochádza k stretu a boju týchto dvoch svetov, $\mathrm{k}$ boju ducha a prírody, slobody a nevyhnutnosti. Indivíduum má biologický pôvod, rodí sa $\mathrm{z}$ otca a matky, je teda determinované rodovou dedičnostou, a rovnako aj sociálnym prostredím. Osobnost' sa naproti tomu nededí z pokolenia na pokolenie, nerodí sa z matky a otca, a preto nie je determinovaná rodovou dedičnostou; osobnost má totiž úplne iný, neprirodzený, nebiologický pôvod: pramení z ducha, rodí sa z Boha.

Avšak ani Boh podla Berdajevovho názoru nijako nedeterminuje, a teda nezotročuje človeka, ale je naopak garantom jeho slobody. Medzi Bohom a človekom nie je a nemôže byt’ vztah pána a raba; Berdajev je presvedčený, že tohto sociomorfizmu ${ }^{5}$ sa treba nadobro zbavit', lebo v histórii to bol a stále aj je jeden zo silných zdrojov ludského otroctva. Berdajevovo poňatie Boha je hlboko humanistické (aj ked' nie v zmysle sekulárneho humanizmu ${ }^{6}$ ). Berd’ajev totiž hlása, že hlavnou Božou vlastnostou je L'udskost ${ }^{7}$ (Berdajev 1997, 70), čo sa podla neho najväčšmi odhalilo v osobe Ježiša Krista. „To človek, sám človek je neludský až hrôza, znetvoruje svoj obraz, Boh je naopak ludský a potrebuje ludskost." (Berdajev 1997, 70). Tým biblickým Božím obrazom v človeku je práve ona ludskost', a preto jedine v ludskosti, slobode a láske sa môžeme a máme Bohu podobat. V knihe Duch a realita Berdajev $(2006,36)$ argumentuje, že je to duch ako základná, konštitučná zložka ludskej osobnosti, ktorý „humanizuje ludské ponímanie Boha a zároveň ho oslobodzuje od hrubého antropomorfizmu“"

Osobnost to nie je jeden z druhu, pretože osobnost' nie je pravidlo, ale výnimka, je to absolútne nóvum; osobnost' značí jedinečnú, neopakovatelnú a nezamenitelnú bytost'. $Z$ tohto dôvodu je napríklad „nehanebné zamenit inou bytostou tú, ktorú ste milovali, v ktorej ste naveky rozpoznali tvár osobnosti.“ (Berdajev 1997, 22). Všetko individuálne je totiž nezamenitelné. V tomto ohlade náš jazyk vnáša menší zmätok do porozumenia rozdielu medzi osobnostou a indivíduom. Všetko osobné je konkrétne a individuálne, osobnost̉ tak označuje to v nás, čo nemáme s nikým iným spoločné. Osobnost’ je preto dokonca individuálnejšia než indivíduum, ktoré je vlastne vždy len jedným z druhu. A oproti indivíduu osobnost̉ nie je súčastou žiadneho univerza, naopak

5 Sociomorfizmus: premietanie našich sociálnych vztahov do vztahu medzi človekom a Bohom.

6 Západnému, sekulárnemu a liberálnemu humanizmu Berdajev predovšetkým vytýka to, že nedostatočne emancipoval človeka od zotročenia prírodou a spoločnostou, že nedokázal garantovat slobodu človeka od sveta (pozri: Berd’ajev 1997, 38).

7 A ako dalej na tom istom mieste dodáva, medzi klúčové Božie vlastnosti patria tiež sloboda, láska a schopnost' obety. 
univerzum je podla Berdajevovho zásadného názoru súčastou osobnosti: osobnost' je „mikrokozmom“. Na rozdiel od nominalizmu, ktorý neuznáva realitu ničoho univerzálneho, Berdajev prehlasuje, že v osobnosti spočíva potencia univerzality. Osobnost’ je však „univerzom v individuálne neopakovatelnej forme a spojením univerza nekonečného a individuálne zvláštneho“ (Berdajev 1997, 20). A na rozdiel od ontologického realizmu Berd’ajev popiera realitu univerzálií mimo osobnosti. „Univerzálne nejestvuje ako bytost mimo osobnosti, ale ako najvyššia náplň života osobnosti a nadosobné hodnoty v nej." (Berdajev 2006, 45). A je to podla Berdajeva (2006, 40) práve duch, ktorý „dáva osobnosti konkrétny univerzálny obsah“.

Ako sme už vyššie uviedli, osobnost' je kategóriou duchovnou. Je však chybou zamieňat si ducha s dušou. Tak ako osobnost̉ nie je biologickou ani sociálnou kategóriou, tak nie je ani kategóriou psychologickou; osobnost̉ totiž nemožno stotožnit's dušou. Berdajev nástojí na tom, že starý dualizmus duše a tela (exemplárne sformulovaný v Descartovej filozofii) treba raz a navždy prekonat’ (pozri: Berdajev 1997, 27). Odmieta rovnako aj abstraktný spiritualistický dualizmus, ktorý stavia ducha do protikladu k telu a ktorý vo svojich etických dôsledkoch vedie k nepriatelskému vztahu $\mathrm{k}$ vlastnému telu. ${ }^{8}$ Namiesto toho prichádza s triadickou štruktúrou ludského bytia: duch, duša a telo. Osobnosṫ možno preto charakterizovat ako duchovno-duševno-telesnú jednotu, pričom túto jednotu kladie duch ako celostný, zjednocujúci a formujúci princíp: „Duch dodáva jednotu ako duši, tak telu, privádza ich k jednote, neprekonáva ich a neničí." (Berdajev 1997, 28). Duch zduchovňuje dušu i telo človeka, a tým ich vyslobodzuje z pút determinizmu prírodného sveta. Telo preniknuté duchovnou formou dosahuje najvyššieho výrazu v ludskej tvári. Tvár človeka totiž nie je podla Berd’ajeva len výslednicou kozmických (prírodných) síl, ale taktiež dôsledkom pôsobenia vnútornej duchovnej energie; práve prostredníctvom ludskej tváre k nám presvitá iný svet (pozri: Berdajev 1997, 27). ${ }^{9}$ Z psychologických pozorovaní môžeme poodhalit, že v duševnom živote konkrétneho človeka predsa len pôsobia mnohé kauzálne podmieňujúce mechanizmy, napríklad ked jeden duševný stav opakovane vyvoláva druhý stav, alebo ked’ rovnaká situácia v živote jedinca vyvoláva u neho zakaždým rovnaké citové reakcie a pod. Znamená to teda, že celý duševný život človeka bezvýhradne podlieha determinácii, že duša človeka je celkom neslobodná? Berdajevova odpoved’ by bola rozhodné „nie“, a dôvod tejto odpovede možno vari najlepšie vyčítat z nasledujúcej pasáže z prvého dielu jeho knihy Filozofia slobodného ducha (1927), kde popisuje vztah medzi dušou a duchom a súčasne pomer duše $\mathrm{k}$ slobode a nevyhnutnosti: „V duševnej realite sa prejavuje sloboda podla toho, nakolko sa v nej prejavuje duchovný svet. Duša človeka je arénou, v ktorej sa vo vzájomnom zápase stretávajú sloboda s nevyhnutnostou, svet duchovný so svetom prírodným. $\mathrm{V}$ duševne totiž pôsobí duch a vtedy sa vyjavuje sloboda ducha. V duševne však pôsobí i príroda, a potom všade vládne nevyhnutnost'. Človek sám seba určuje zvnútra, z hlbiny podla toho, nakolko v ňom zvítazil duch nad duševnými a prírodnými živlami, podla toho, nakolko duša vstúpila do ducha a sama bola duchom preniknutá." (Berdajev 2009, 172-173). Koniec koncov to teda závisí predovšetkým od osobnosti samotnej, od jej vlastného duchovného zápasu, nakol'ko jej dušu ovládne prírodná determinácia, alebo nakol'ko v nej zvítazí sloboda.

Tak ako tvrdili mnohí myslitelia už pred Berd’ajevom, napr. Pascal alebo Nietzsche, človeku je vlastné prekračovat’ seba samého. A podla Berdajeva jestvujú dva možné spôsoby, ako môže človek prekročit seba samého, ako môže vyjst̉ z uzavretej subjektivity. Tým prvým je objektivácia. Termín

8 V tomto ohlade, teda pokial' ide o konštitúciu ludskej bytosti, má Peter Grečo interpretujúci Berdajevovo dielo pravdu, ked' vznáša požiadavku prekonania starobylého dualizmu založeného na protiklade duše a tela, ktorý napokon vedie k negatívnym dôsledkom v praktickom živote človeka (Grečo 2017, 91-92). Na druhej strane však treba dodat’, že Berd’ajev vždy hlásal potrebu metafyzického dualizmu, bez ktorého by podla jeho názoru nebolo možné vybudovat pravú filozofiu slobody, ducha a osobnosti.

9 V tejto súvislosti nie je bez zaujímavosti, že pre tvár a osobu má ruština rovnaké slovo: лицо. 
objektivácia je klúčovým pojmom celej Berd’ajevovej filozofie, ktorým popisuje takmer všadeprítomný negatívny proces, v ktorom dochádza k odcudzeniu subjektu sebe samému. Objektivácia v skratke znamená spredmetnenie, exteriorizáciu, socializáciu, racionalizáciu a symbolizáciu. Objektiváciu Berdajev odhaluje ako hlavný zdroj zotročenia osobnosti. „Objektivácia predstavuje neosobnost', vyvrhnutost' človeka v determinovaný svet.“ (Berd’ajev 1997, 24). Tou druhou cestou, ako sa možno dostat’ von z uzavretej subjektivity, je transcendencia, ktorá je opakom objektivácie. Práve transcendencia je jedinou cestou, na ktorej dochádza ku skutočnej realizácii osobnosti. Na rozdiel od objektivácie, transcendencia neznamená prechod subjektivity k objektivite, ale subjektivity k transubjektivite. „Táto cesta vedie hlbinou existencie, na nej dochádza k existenciálnym stretnutiam s Bohom, s druhým človekom, s vnútorným bytím sveta; nie je to cesta objektívnych vztahov, ale vztahov existenciálnych." (Berdajev 1997, 26). Transcendencia je teda cestou od subjektivity k subjektivite, od osobnosti k osobnosti, pričom i Boh sám tu vystupuje ako subjekt, i Boh je totiž osobnostou. Z tohto dôvodu by sme naň nikdy nemali nahliadat ako na objekt, pretože taký vztah k Bohu by viedol len k jeho objektivácii, a teda skreslenému obrazu skutočného Boha, čoho možným dôsledkom by bola idolatria, a tým taktiež zotročenie našej osobnosti. Transcendencia je aktívny, dynamický proces, ktorý sa azda napohlad paradoxne uskutočňuje v imanencii, konkrétne v imanentnej, vnútornej, duchovnej skúsenosti. Preto transcendencia nie je v skutočnosti exteriorizáciou, ale naopak interiorizáciou.

S vyššie popísanou pojmovou diferenciou osobnosṫ/indivíduum bezprostredne súvisí aj Berdajevovo rozlišovanie medzi personalizmom a individualizmom. Berdajev nás dôrazne vystríha, aby sme si tieto dva „izmy“ navzájom nezamieňali. Individualizmus, ktorý stojí v pozadí liberalizmu a tzv. buržoázneho alebo meštiackeho vedomia, je založený na atomizácii jedinca a na jeho egoistickom sebapotvrdení, a ako taký je vskutku antipersonalistický. Naproti tomu personalizmus napriek svojmu primárnemu dôrazu na slobodu osobnosti a jej nezávislosti na prírode a spoločnosti nevedie človeka do izolácie, ale vychádza z predpokladu, že osobnost̉ sa môže plne realizovat iba v transcendencii. A navzdory tomu, že individualizmus sa vyznačuje túžbou po nezávislosti a všemožne sa ženie za slobodou, podla Berdajeva $(1997,30)$, v skutočnosti „... vôbec neznamená nezávislost̉ vo vztahu k celku, k dianiu kozmickému, biologickému a sociálnemu, ale iba izoláciu podriadenej časti a jej zúfalú vzburu proti celku“.

Jedným z najpodstatnejších určení osobnosti je podla Berdajeva $(1997,10)$ to, že „[o]sobnost” je tým nemenným v zmenách.... Na druhej strane inou podstatnou črtou osobnosti je to, že je dynamická, že v nej niet nijakého nehybného stavu. To nás stavia pred otázku, ako uviest’ do jednoty tieto napohlad protikladné Berdajevove charakteristiky osobnosti. Berdajev $(1997,21)$ nám na to sám odpovedá: „Osobnost nie je stuhnutým stavom, rozoviera sa, rozvíja sa, obohacuje sa, ale ide o rozvoj jedného a toho istého celkom určitého jestvujúceho subjektu“. Spojenie zmeny a stálosti v osobnosti má podla môjho názoru v Berdajevovej filozofii osobnosti dve roviny. Prvá je ontologická, teda tá, ktorú sme si práve Berdajevovým citátom teraz približili. V tejto ontologickej rovine ide o identitu osobnosti: totiž, že napriek všetkým zmenám, napriek tomu, že sa ako osobnost’ permanentne rozvíjam a realizujem tvorivým aktom, som to predsa stále ja, a nie som teraz nikým iným, než kým som bol pred piatimi či desiatimi rokmi. Druhá rovina je etická: ak človek sám seba zrádza, sám sebe si je neverný, to znamená, mení sa v premenách doby pod tlakom vonkajších okolností, motivovaný vlastným konformizmom a oportunizmom, jeho osobnost’ sa začne rozpadat. Iba ten, kto zostáva aj napriek všetkým vonkajším, sociálnym či politickým zmenám vo svojom charaktere nezmenený, iba taký človek môže byt právom nazývaný osobnostou. Teda osobnostou v prísnom slova zmysle je iba človek s pevnou morálnou integritou. Ako píše Berdajev $(1997,25)$ : „Osobnost' je spätá s pamätou a vernostou, s jednotou osudu a jednotou biografie“.

Z vyššie uvedeného je zrejmé, že Berdajev používa pojem osobnosti v dvojakom zmysle. V širšom zmysle je každá z ludských bytostí osobnostou, každý z nás má predsa svoj „existenciálny 
stred“ (Berdajev 1997, 21), to znamená, že každý jeden z nás je subjektom svojej existencie, je subjektom vlastnej tvorivej aktivity a je schopný sa vcítit do utrpenia i radosti druhého človeka. Možno povedat, že v tomto prípade hovorí Berdajev o osobnosti v antropologickom zmysle slova. No v užšom zmysle slova osobnost’ Berd’ajev vo svojom diele odkazuje na výzvu, ktorá tu vyvstáva pred každým z nás - osobnost je $\mathrm{v}$ tomto prípade niečo, $\mathrm{k}$ čomu sa len môžeme a v etickom zmysle zároveň aj máme dopracovat'. V tomto druhom, užšom zmysle Berdajev $(1997,21)$ považuje osobnost' za axiologickú, teda hodnotovú kategóriu a v tomto duchu píše, že „[o]sobnost' nie je v žiadnom prípade hotovou danostou, ale je úlohou, ideálom človeka“. Obidva tieto významy pojmu osobnost’ sa potom stretávajú v jeho nasledujúcej myšlienke: „Osobnost’ je na počiatku a taktiež na konci cesty.“ (Berd’ajev 1997, 21). Azda keby bol Berd’ajev terminologicky dôslednejší, volil by pre antropologický pojem, ktorý mu slúži na deskripciu jedinečnosti každej ludskej bytosti, výraz „оsoba“ (лицо) a pre axiologický, resp. etický pojem, ktorým charakterizuje ciel', o ktorý sa má usilovat každá osoba, termín „osobnost“ (личность).

V otvorenej nadväznosti na Kanta, no na míle d’aleko od jeho racionalizmu a etického formalizmu, poukazuje Berdajev na to, že človek ako osobnost’ je vždy cielom o sebe, a z toho dôvodu sa nemôže stat prostriedkom, či už druhých ludí, spoločnosti ako celku, alebo samotného Boha. Ked' sa človek stáva pre druhého prostriedkom, znamená to, že sa mu stáva objektom jeho vlastných túžob a zámerov. Rozpoznat v druhom človeku osobnost̉ značí prestat ho vnímat ako objekt, ale začat' ho vnímat v jeho subjektivite, alebo inak povedané, znamená to, že „ja“ vystúpi z egocentrickej uzavretosti v sebe a vstúpi do spoločenstva s „ty“. A práve v tom, že človek je definovaný ako osobnost', to znamená ako jedinečná, originálna, slobodná a tvorivá bytost’ s potenciálnym univerzálnym obsahom, obrazom Božím v sebe a schopnostou transcendencie, spočíva jeho skutočná dôstojnost' (pozri: Berd’ajev 1997, 24). Berdajevov celoživotný zápas za slobodu, ktorý viedol nielen perom $\mathrm{v}$ textoch svojich početných kníh a v mnohých publicistických článkoch, ale aj vernostou tomuto svojmu poslaniu v osobnom živote na pozadí velkých a krutých politicko-spoločenských zmien ${ }^{10}$, bol zároveň aj jeho vášnivým bojom za osobnost’ a jej dôstojnost' - ako zdôraznil v autobiografickej knihe Sebapoznanie: nejde o to zápasit za právo každého človeka na štastie, ale za dôstojnost' každej jednotlivej ludskej osoby (porovnaj: Berd’ajev 2005, 48).

\section{REFERENCES}

Berd’ajev, Nikolaj Alexandrovič. 2000. Dostojevského pojetí světa. [Dostoevsky]. Praha.

Berd’ajev, Nikolaj Alexandrovič. 2006. Duch a realita. Základy boholudskej duchovnosti [The Spirit and Reality]. Bratislava.

Berd’ajev, Nikolaj Alexandrovič. 2009. Filosofie svobodného ducha. Apologie

a problematika křestanství. Čast' 1. [The Philosophy of a Free Spirit, vol. I.]. Červený Kostelec.

Berd’ajev, Nikolaj Alexandrovič. 1997. O otroctví a svobodě člověka. Pokus o personalistickou filosofii. [Slavery and Freedom]. Praha.

Berdajev, Nikolaj Alexandrovič. 2003. Ríša Ducha a ríša Cisárova. [The Realm of the Spirit and the Realm of the Ceasar]. Bratislava.

Berd’ajev, Nikolaj Alexandrovič. 2005. Sebapoznanie. Pokus o filozofickú autobiografiu. [Selfknowledge: An Essay in Autobiography]. Bratislava.

10 Pripomeňme len zopár faktov z jeho života: Berdajev za starého (cárskeho) i za nového (bolševického) režimu bol pre svoje názory zo strany vládnej moci, napriek tomu, že sám nikdy nebol priamo politicky činný, niekolkokrát vystavený policajnému vypočúvaniu, štyrikrát bol odsúdený na pobyt vo väzení a dvakrát bol poslaný do vyhnanstva (raz z toho nenávratne preč zo svojej rodnej zeme). 
Grečo, Peter. 2017. Princípy existenciálneho personalizmu v kontexte byzantskej antropológie. [The Principles of the Existential Personalism in the Context of the Byzantine Anthropology]. In Konštantínove listy [Constantine's Letters] 10/1, 83-97.

Jabưrek, Martin. 2013. Eschatologický existencializmus Nikolaje Berdajeva. Brno.

Kierkegaard, Søren. 1993. Bázeň a chvění. Nemoc k smrti. Praha.

Letz, Ján. 2004. Personalistická filozofia Nikolaja Alexandroviča Berd’ajeva. In RaN 2004/2, 33-43. http://www.uski.sk/frm_2009/ran/2004/ran-2004-2-03.pdf.

Marcel, Gabriel. 1971. K filosofii naděje. Praha.

Pružinec, Tomáš. 2017. Človek a technika. Náčrt problematiky na pozadí myšlienok Nikolaja Alexandroviča Berdajeva. In Feber, Jaromír - Rusnák, Peter: Reflexia človeka v slovanskom filozofickom prostredí. Acta Moralia Tyrnaviensia VII. Trnava, 134-144.

\begin{abstract}
SUMMARY: THE CONCEPT OF PERSONALITY IN THE WORK OF RUSSIAN PHILOSOPHER NIKOLAI ALEXANDROVICH BERDYAEV (CLIMAX OF THE PERSONALISTIC LINE OF SLAVIC THOUGHT). In the paper I tried to shed light on the concept of personality as a key concept in the work of N. A. Berdyaev, whose thought can be seen as a climax of the personalistic line of Slavic philosophy (although not in a chronological meaning). Therefore it is primarily concerned with Berdyaev's principal book Slavery and Freedom (1939), where this theme is elaborated most thoroughly. Berdyaev's concept of personality is here interpreted in correlation with other central concepts of his work, above all with freedom and spirit - both are exposed as the inherent attributes of personality. That is why I suggested that any materialistic or deterministic concept of personality must prove as self-contradictory. While Berdyaev's metaphysics is primarily based on duality of spirit and nature, or freedom and necessity and he views this metaphysical dualism as an ontological precondition for the existence of personality, I pointed to the fact that his concept of person(ality) is based on the triple structure: spirit, soul and body. In the paper, I also examined Berdyaev's fundamental conceptual distinctions between personality and individual; while personality is regarded as a spiritual category, the individual is understood as a biological, sociological or psychological category. Then I outlined the differences in standpoints of personalism and individualism, while the latter was shown as opposed to the former. In the end, I interpreted Berdyaev's personalism as part of his lifelong philosophical and personal fight for dignity of every single human person.
\end{abstract}

Mgr. Milan Petkanič, PhD.

The University of Ss. Cyril and Methodius

Faculty of Arts

Department of Philosophy and Applied Philosophy

Nám. J. Herdu 2

91701 Trnava

Slovakia

milan.petkanic@ucm.sk 